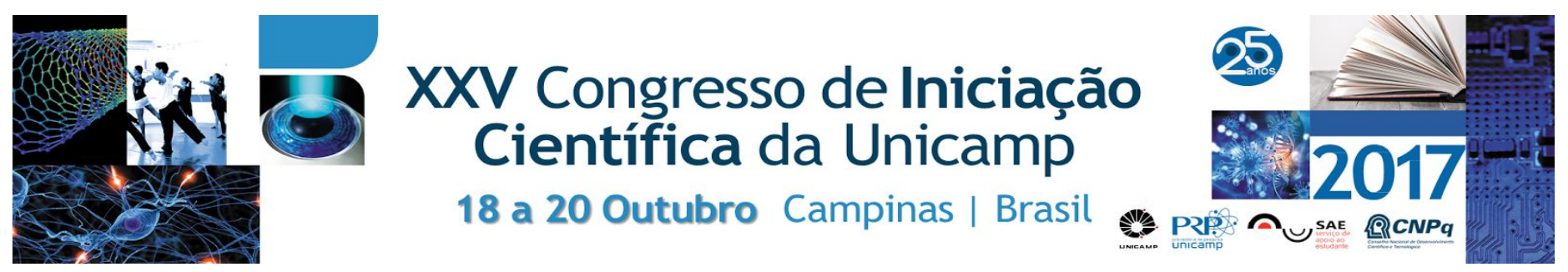

\title{
Decomposição de matéria orgânica vegetal e animal: um estudo comparativo
}

\section{Paula Pinheiro Morão*, Bruna Toledo Nunes Pereira, Meg Cristina Canabarro Zecchin, José Roberto Trigo Resumo}

A decomposição da matéria orgânica é um processo natural de reciclagem que resulta na transformação de compostos orgânicos mais complexos em compostos inorgânicos que posteriormente serão reintegrados aos diferentes ciclos de vida de organismos. O presente estudo comparou a taxa de decomposição entre matérias orgânicas de origem vegetal e animal. Utilizamos $500 \mathrm{~g}$ de folhas secas e $100 \mathrm{~g}$ de carne de origem bovina, com 10 repetições cada. O material foi depositado em bolsas de confinamento (litterbags) e distribuído separadamente na área experimental, em contato com o solo. Nos dias 3,7 e 21, as bolsas foram pesadas e a taxa de decomposição dos materiais foi quantificada medindo-se a massa remanescente. Verificamos que a taxa de decomposição de matéria orgânica animal é significativamente maior que a taxa de decomposição da matéria orgânica vegetal. Isso é explicado pela maior quantidade de proteínas, lipídeos e açúcares na matéria animal, os quais decompõem rapidamente, em comparação com a maior quantidade de celulose e ligninas no material vegetal, os quais decompõem vagarosamente.

\section{Palavras-chave:}

Ciclagem de nutrientes, decomposição, litterbags

\section{Introdução}

Em um ecossistema terrestre, o solo é fonte essencial de moléculas orgânicas, que servirão de nutriente aos organismos que compõe o sistema. Para que toda essa dinâmica ocorra, faz-se necessário que aconteça a decomposição das matérias vegetais e animais. Tanto fatores abióticos, como temperatura e volume de precipitação, quanto fatores bióticos, como a composição do material a ser decomposto influenciam na dinâmica de decomposição ${ }^{1}$. Dentro desse contexto nosso trabalho estudou a taxa de decomposição da matéria orgânica vegetal, representada por folhas que compunham a serapilheira, e da matéria orgânica animal, representada por pedaços de carne in natura, com a finalidade de confirmar que a diferença na composição do substrato a ser decomposto influencia na taxa de decomposição.

\section{Resultados e Discussão}

Foram confeccionadas 20 bolsas de náilon (litterbags). Cinco gramas de cada materia orgânica foram colocadas, separadamente, dentro de cada litterbag, com 10 réplicas para cada tipo de matéria orgânica. Nos dias 3 , 7 e 21, a matéria orgânica foi pesada. Ao fim do experimento, as amostras foram secas em estufa a $60^{\circ} \mathrm{C}$ por 48 horas até peso constante e repesadas para obtenção dos valores de massa seca. Os valores obtidos durante o experimento nos tempos $0,3,7$ e 21 foram corrigidos considerando a proporção de massa seca das amostras.

A proporção de massa remanescente foi significativamente maior no material orgânico vegetal em comparação com o animal (Anova de medidas repetidas, $\mathrm{F}_{1,18}=4990,160, \mathrm{P}<0,001$, Figura 1). A proporção de massa remanescente decresceu significativamente mais, ao longo do tempo, no material orgânico animal em comparação com o vegetal $\left(F_{2,36}=712,25, P<0,001\right.$, Figura 1). Enquanto a porcentagem de matéria animal decomposta atingiu quase $90 \%$ ao final dos 21 dias, a porcentagem de matéria vegetal decomposta foi aproximadamente $25 \%$ para o mesmo período de tempo.

A resistência da parede celular de compostos orgânicos vegetais é o principal fator que retarda sua decomposição. Com isso, devido a matéria orgânica animal ser majoritariamente composta por proteínas, a sua decomposição acontecerá muito mais rápido quando comparada com a decomposição da matéria vegetal.

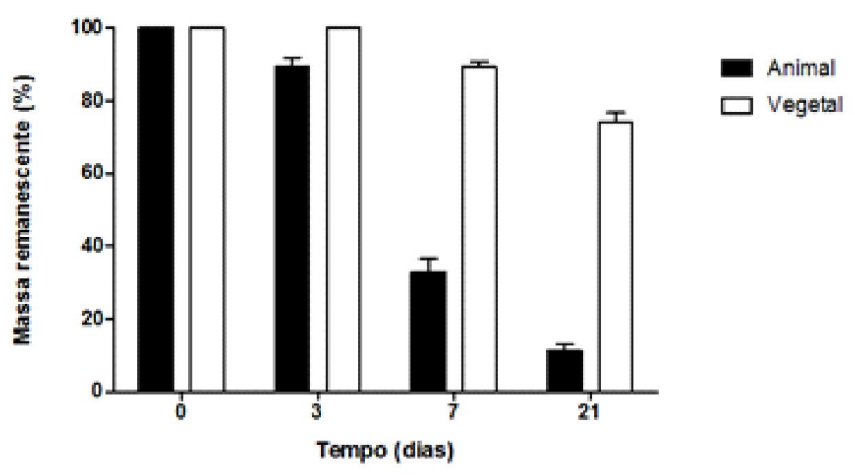

Figura 1. Porcentagem de massa remanescente animal e vegetal ao longo do tempo.

\section{Conclusões}

Concluímos que a composição da matéria orgânica estudada influencia a taxa de decomposição desses sistemas.

\section{Agradecimentos}

Esse trabalho foi desenvolvido na disciplina BE682 Prática em Ecologia de Organismos, Populações, Comunidades e Ecossitemas, do Curso de Graduação em Licenciatura em Ciências Biológicas.

${ }^{1}$ Begon, M., Townsend, C. R., Harper, J.L. (2007) Decompositores e detritívoros In: Ecologia de Indivíduos a Ecossistemas. Blackwell Publishing Ltd. Oxford. Cap 11, p.326-346. 